\title{
ANALISA PENGARUH BIAYA PROMOSI DAN HARGA JUAL TERHADAP VOLUME PENJUALAN PADA PERUSAHAAN PROPERTI DI DAERAH LAMPUNG
}

\author{
Andreas Aswin \\ Program Studi Magister Manajemen Universitas Tarumanagara \\ andreas.aswin6195@gmail.com \\ Riris Loisa \\ Program Studi Magister Manajemen Universitas Tarumanagara
}

\begin{abstract}
Buying things is an activity that has been done since the first age of humanity. People buy things to fulfill living needs, may it be primary, secondary, or tertiary needs. At first humans used barter system, where people trade an item for another things, such as service or goods. Nowadays human uses money for buying things, and today, Indonesia economic power is rising among the globe. Based on that increase, people get more income, and upgrade their lifestyle. One of the things to buy for such need is property. When it comes to property, like other things, people will look into promotion and selling price, thus the two variables has been used for this research. The goal of this research is to understand whether those two variables has impact or not to selling volume. The data used for making this research is from a property company based in Lampung. The data was taken from the company annual yearly monetary report from year 2015 to 2018 . One factor to take note is that the selling price was controlled by government since the company was selling government subsidiary backed houses, therefore the only variable that the company can fully control was the promotion cost. The conclusion was that the price doesn't affect much of the selling volume, therefore the company should focus on better promotion programs.
\end{abstract}

Keywords : Promotion Cost, Selling Price, Selling Volume

\begin{abstract}
Abstrak : Membeli barang adalah sebuah aktivitas yang telah dilakukan sejak awal manusia muncul. Masyarakat membeli barang barang untuk memenuhi kebutuhan hidup, baik primer, sekunder, atau tersier. Pada awalnya manusia menggunakan sistem barter, dimana kegiatan jual beli dilakukan dengan menukar satu barang dengan lainnya, seperti jasa atau produk. Sekarang uang telah menggantikan fungsi barter, dan saat ini, kekuatan ekonomi Indonesia sedang meningkat secara global. Didasari pada peningkatan tersebut, masyarakat mendapatkan pendapatan lebih, dan menaikkan gaya hidup mereka. Salah satu hal yang dibeli untuk memenuhi kebutuhan tersebut adalah properti. Ketika membeli properti, sama seperti banyak hal lainnya, orang-orang akan melirik promosi dan harga jual, sehingga kedua variabel tersebut digunakan untuk penelitian ini. Tujuan penelitian ini adalah untuk mengerti apakah kedua variabel tersebut memiliki pengaruh atau tidak terhadap volume penjualan. Jenis penelitian yang dilakukan adalah penelitian kuantitatif. Data yang digunakan untuk membuat penelitian ini berasal dari Perusahaan Properti di Daerah Lampung. Data diambil dari laporan keuangan tahunan perusahaan dari tahun 2015 sampai tahun 2018. Satu faktor yang perlu diketahui adalah harga jual perusahaan tersebut dikontrol oleh pemerintah, karena produk yang dijual adalah rumah subsidi pemerintah, sehingga variabel yang dalam kendali penuh perusahaan adalah biaya promosi. Kesimpulan yang diperoleh adalah harga tidak mempengaruhi volume penjualan, sehingga perusahaan sebaiknya focus pada perencanaan promosi yang lebih baik.
\end{abstract}

Kata Kunci : Biaya Promosi, Harga Jual, Volume Penjualan 


\section{PENDAHULUAN}

Berbelanja adalah suatu kegiatan yang telah dilakukan sejak jaman purba. Manusia berbelanja untuk memenuhi kebutuhan hidup, baik primer, sekunder maupun tersier. Pada awalnya, manusia menggunakan sistem barter, yaitu menukarkan suatu barang untuk mendapatkan barang lain yang diinginkan.

Pada masa ini, sebagai ganti sistem barter, manusia menggunakan uang sebagai alat tukar. Salah satu cara mendapatkan uang yaitu dengan bekerja, baik pada suatu perusahaan tertentu, maupun bekerja sendiri. Dengan meningkatnya pendapatan seseorang, kemampuan ekonomi dan berbelanja orang tersebut juga akan ikut naik.

Menteri Keuangan Sri Mulyani Indrawati mengatakan di tengah kondisi perekonomian global yang tengah melorot, namun pertumbuhan ekonomi Indonesia pada tahun 2016 termasuk yang tertinggi di dunia (sindonews.com, 17 November 2016). Menurut Sri Mulyani, meski banyak negara produsen komoditas mengalami pukulan namun Indonesia masih memiliki kemampuan untuk menjaga pertumbuhan ekonominya yang pada kuartal III/2016 tumbuh 5,04\%. Pertumbuhan ekonomi Indonesia bisa tumbuh kuartal III sebesar 5,04\% ditopang pertumbuhan konsumsi sangat sehat, inflasi masih rendah 3,7\% dan dari sisi investasi masih tumbuh mendekati $5 \%$.

Dalam memilih properti yang ditawarkan dari sebuah pengembang, seorang investor akan memperhatikan beberapa hal, seperti promosi yang dijalankan oleh pengembang, dan tentunya harga yang diberikan. Seorang investor akan menilai apakah promosi yang diberitakan sesuai dengan kenyataan yang ada di lapangan. Dalam Promosi yang dilakukan oleh perusahaan tersebut akan menyebabkan biaya promosi. Mowen (1993) berpendapat konsumen cenderung menggunakan harga sebagai sebuah indikator kualitas. Menurut McCarthy (1964), promosi adalah suatu metode untuk memberitahukan, membujuk, atau mengingatkan konsumen tentang produk, tempat, dan harga yang telah disusun oleh manajer pemasaran. Selain itu hal yang menjadi pertimbangan lainnya yaitu harga yang ditawarkan pada properti yang dijual sesuai dengan nilai properti tersebut.

Dalam penelitian ini penulis akan menggunakan data yang didapatkan dari sebuah perusahaan properti yang berdomisili di daerah Lampung. Data yang akan digunakan yaitu harga jual, biaya promosi, dan volume penjualan. Perusahaan tersebut bergerak dalam bidang perumahan bersubsidi. Subsidi yang dimaksud adalah subsidi dari pemerintah. Saat ini bisnis perumahan subsidi sedang menjadi berita hangat, karena termasuk juga dalam program pemerintah. Hingga Februari 2018, pertumbuhan kredit pemilikan rumah sudah mencapai 20\% (liputan6.com, 5 Februari 2018).

Dengan berbagai macam pertimbangan yang telah disebutkan, penulis hendak melakukan penelitian terhadap faktor-faktor yang mempengaruhi volume penjualan berdasarkan harga jual, serta biaya promosi yang dilakukan perusahaan tersebut. Kotler (2000) berkata volume penjualan adalah barang yang terjual dalam bentuk uang untuk jangka waktu tertentu dan didalamnya mempunyai strategi pelayanan yang baik. Penelitian ini diharapkan akan menjadi acuan untuk semakin memajukan usaha perusahaan tersebut.

Berdasarkan pendahuluan tersebut, maka didapatkan masalah yang akan diteliti adalah: Seberapa kuat pengaruh pengaruh biaya promosi sebuah perusahaan properti di daerah Lampung terhadap besarnya volume penjualan perusahaan tersebut, serta seberapa kuat pengaruh harga jual properti sebuah perusahaan properti di daerah Lampung terhadap besarnya volume penjualan perusahaan tersebut.

\section{METODE PENELITIAN}

Penelitian ini menggunakan pendekatan kuantitatif. Menurut Sugiyono (2015), dalam penelitian kuantitatif, masalah yang dibawa oleh peneliti harus sudah jelas, sedangkan masalah dalam penelitian kualitatif masih bersifat sementara dan akan berkembang setelah peneliti memasuki lapangan. Metode penelitian yang dilakukan adalah penelitian deskriptif 
korelasional. Penelitian deskriptif digunakan untuk memberikan penjelasan karakteristik mengenai objek penelitian, dengan tujuan untuk mendapatkan pengertian mengenai karakteristik, profil, serta dapat pula menjelaskan aspek yang relevan dari fenomena tehadap objek penelitian, sehingga dapat ditarik suatu gambaran bahwa penelitian deskriptif digunakan untuk memberi deskripsi atau gambaran terhadap objek yang diteliti. Dalam penelitian ini, pendekatan deskriptif digunakan untuk memberi gambaran mengenai biaya promosi yang dikeluarkan oleh Perusahaan Properti di Daerah Lampung dan harga jual yang ditawarkan oleh perusahaan tersebut dalam jangka periode per satu tahun.

Adapun pendekatan korelasional digunakan untuk menunjukkan adanya hubungan antara dua variabel. Tujuan pendekatan korelasional adalah untuk menentukan ada atau tidaknya suatu hubungan antara beberapa variabel tersebut. Demikian juga dalam penelitian ini, dimana pendekatan korelasional digunakan untuk mengetahui seberapa besar pengaruh besar biaya yang digunakan untuk melakukan promosi dan harga jual yang ditawarkan oleh Perusahaan Properti di Daerah Lampung terhadap volume penjualan.

Metode analisis yang digunakan yaitu analisis regresi linear berganda, dengan metode analisis tersebut akan terlihat hubungan antara variabel independent terhadap variabel dependen. Rumus yang digunakan berdasarkan Riduwan dan Akdon (2007):

$$
\mathrm{Y}=\mathrm{b}_{0}+\mathrm{b}_{1} \mathrm{X}_{1}+\mathrm{b}_{2} \mathrm{X}_{2}+\mathrm{e}
$$

Dimana :

$\mathrm{Y}=$ Volume penjualan (unit terjual)

$\mathrm{X}_{1}=$ Harga jual (Rupiah)

$\mathrm{X}_{2}=$ Biaya promosi (Rupiah)

$\mathrm{b}_{0}=$ Nilai konstanta

$\mathrm{b}_{1}, \mathrm{~b}_{2}=$ Koefisien regresi

Selain itu juga akan dilakukan uji asumsi klasik normalitas dan heteroskedastisitas.

\section{HASIL DAN PEMBAHASAN HASIL}

Tabel 1. Deskripsi Nilai Biaya Promosi, Harga Jual, dan Volume Penjualan

\section{Descriptive Statistics}

\begin{tabular}{lr|r|r} 
& \multicolumn{1}{c|}{ Mean } & Std. Deviation & N \\
\hline Volume & 230.00 & 29.439 & 4 \\
\hline Harga & 120000000.0 & 8396427.812 & 4 \\
\hline Biaya Promosi & 1794225000 & 480401917.7 & 4 \\
\hline
\end{tabular}

Dalam Sugiyono (2015) Analisis deskriptif merupakan analisis yang digunakan untuk menganalisis data dengan mendeskripsikan/ menggambarkan data yang telah terkumpul sebagaimana adanya tanpa bermaksud untuk membuat suatu kesimpulan yang berlaku umum atau generalisasi.

Berdasarkan Tabel 1, dapat ditarik deskripsi umum sebagai berikut:

1. Data Volume penjualan memiliki nilai rata rata 230, dengan deviasi standar 29,439, dimana deviasi standar lebih kecil daripada rata rata.

2. Data Harga Jual memiliki nilai rata rata 120000000 , dengan deviasi standar 8396427,812 .

3. Hasil dari statistik deskriptif pada tabel tersebut menunjukkan bahwa rata-rata volume penjualan sebesar 230, dengan deviasi standar sebesar 29,439. 

berikut:

Berdasarkan hasil pengujian di atas maka didapatkan persamaan regresinya yaitu sebagai

$$
\begin{aligned}
& Y^{\prime}=a+b_{1} X_{1}+b_{2} X_{2} \\
& Y^{\prime}=548,035+(-0,004795) X 1+0,0014343 X 2
\end{aligned}
$$

Keterangan :

$\mathrm{Y}^{\prime} \quad=$ Volume Penjualan

A $\quad=$ Konstanta

$\mathrm{b}_{1}, \mathrm{~b}_{2}=$ Koefisien Regresi

$\mathrm{X}_{1} \quad=$ Harga

$\mathrm{X}_{2} \quad=$ Biaya Promosi

Berdasarkan tabel tersebut hasil yang telah diperoleh dari koefisien regresi, maka dapat dilihat bahwa nilai konstantanya yaitu 548,035 artinya jika harga (X1) dan biaya promosi (X2) nilainya 0 maka volume penjualan nilainya 548,035. Dan juga terjadi korelasi negatif antara variabel harga dengan variabel volume penjualan.

Pengujian hipotesis menggunakan uji $\mathrm{t}$ dan $\mathrm{F}$, dengan hasil sebagai berikut:

Tabel 2. Hasil Uji t

Coefficients $^{\mathrm{a}}$

\begin{tabular}{ll|r|r}
\multicolumn{2}{c}{ Model } & \multicolumn{2}{c}{ Sig. } \\
\hline 1 & (Constant) & .895 & .535 \\
\cline { 2 - 4 } & Harga & -.696 & .613 \\
\cline { 2 - 4 } & Biaya Promosi & 1.191 & .445 \\
\hline
\end{tabular}

a. Dependent Variable: Volume

Pada tabel di atas, hasil uji t variabel Harga $\left(\mathrm{X}_{1}\right)$ terhadap Volume Penjualan (Y) menunjukan tingkat signifikansi 0,6 > 0,05. Karena tingkat signifikansi $>0,05$, dan juga berdasarkan tabel didapat $\mathrm{t}$ hitung sebesar $-0,696$ dan didapatkan $\mathrm{t}$ tabel sebesar 12,71 (ms.excel(=tinv0.025,1), -0,696 > -12,71 artinya $-\mathrm{t} \mathrm{t}_{\text {hitung }}>-\mathrm{t}$ tabel, maka dapat disimpulkan bahwa tidak terdapat pengaruh yang signifikan antara variabel harga terhadap volume penjualan yang artinya secara parsial tidak terdapat pengaruh yang signifikan antara variabel harga terhadap variabel volume penjualan. Jadi hasil analisis di atas menunjukan bahwa variabel harga secara parsialtidak berpengaruh terhadap volume penjualan rumah Sebuah Perusahaan Properti di Lampung.

Pada tabel di atas, hasil uji t variabel Harga (X1) terhadap Volume Penjualan (Y) menunjukan tingkat signifikansi 0,4 >0,05. Karena tingkat signifikansi $>0,05$, dan juga berdasarkan tabel didapat $\mathrm{t}$ hitung sebesar 1,191 dan didapatkan $\mathrm{t}$ tabel sebesar 12,71 (ms.excel(=tinv0.025,1), 1,191 > 12,71 artinya t thitung > t tabel, dapat disimpulkan bahwa tidak terdapat pengaruh yang signifikan antara variabel harga terhadap volume penjualan yang artinya secara parsial tidak terdapat pengaruh yang signifikan antara variabel harga terhadap variabel volume penjualan. Jadi hasil analisis di atas menunjukan bahwa variabel promosi secara parsial tidak berpengaruh terhadap volume penjualan rumah Sebuah Perusahaan Properti di Lampung.

\begin{tabular}{ll|r|r|r|r|r}
\multicolumn{7}{c}{ Tabel 3. Hasil Uji F } \\
Model & & Sum of Squares & \multicolumn{1}{c}{ df } & Mean Square & \multicolumn{1}{c}{ F } & Sig. \\
\hline 1 & Regression & 2524.355 & 2 & 1262.178 & 16.686 & $.171^{\text {b }}$ \\
\cline { 2 - 8 } & Residual & 75.645 & 1 & 75.645 & & \\
\cline { 2 - 8 } & Total & 2600.000 & 3 & & & \\
\hline
\end{tabular}

a. Dependent Variable: Volume

b. Predictors: (Constant), Biaya Promosi, Harga 
Dari hasil pengujian di atas, karena tingkat signifikansi $<\alpha$ dan didapatkan $\mathrm{F}_{\text {hitung }}$ sebesar 16,686 > 199 dari $\mathrm{F}_{\text {tabel }}$ maka dapat dikatakan bahwa variabel harga dan biaya promosi secara bersama-sama (simultan) berpengaruh signifikan terhadap variabel volume penjualan.

\section{KESIMPULAN DAN SARAN}

Penelitian ini dilakukan untuk mengetahui pengaruh harga dan biaya promosi terhadap volume penjualan Sebuah Perusahaan Properti di Lampung pada tahun 2015-2018. Berdasarkan data yang telah diteliti maka dapat disimpulkan sebagai berikut:

1. Harga tidak memiliki pengaruh yang signifikan terhadap volume penjualan Sebuah Perusahaan Properti di Lampung.

2. Biaya promosi tidak memiliki pengaruh yang signifikan terhadap volume penjualan Sebuah Perusahaan Properti di Lampung.

3. Hasil pengujian mengatakan bahwa variabel harga (X1) dan variabel biaya promosi (X2) secara simultan memiliki pengaruh yang sangat kuat terhadap volume penjualan rumah. Berdasarkan kesimpulan-kesimpulan di atas maka penulis menyarankan beberapa hal sebagai berikut:

1. Kepada Sebuah Perusahaan Properti di Lampung

Mengingat kedua faktor secara bersama memiliki pengaruh yang sangat kuat terhadap volume penjualan, maka perusahaan perlu memperhatikan kegiatan promosi yang dilaksanakan agar dapat lebih menarik perhatian para pembeli. Di satu sisi, harga penjualan yang merupakan harga subsidi secara parsial tidak memiliki pengaruh terhadap volume penjualan, sehingga harga tidak menjadi masalah, apalagi perusahaan tidak memiliki kuasa atas pengaturan harga, selain menurunkan dari standar yang diberikan pemerintah, namun menurunkan harga berarti dapat menurunkan laba. Oleh karena itu, pengaturan strategi promosi yang baik akan lebih membantu penjualan untuk kedepannya.

2. Kepada Peneliti

Melihat dari hasil penelitian yang memiliki banyak keterbatasan ini, peneliti selanjutnya diharapkan dapat menggunakan faktor-faktor lainnya seperti produk, lokasi proyek, dan kualitas bangunan yang kemungkinan mempengaruhi volume penjualan selain harga dan biaya promosi dengan referensi yang lebih banyak.

\section{DAFTAR PUSTAKA}

Akdon, Riduwan. (2007). Rumus dan Data dalam Aplikasi Statistika. Bandung: Alfabeta.

Fajriah, Lily Rusna. (2016). Sri Mulyani: Pertumbuhan Ekonomi Indonesia Termasuk Tertinggi di Dunia. https://ekbis.sindonews.com/read/1156211/33/sri-mulyanipertumbuhan-ekonomi-indonesia-termasuk-tertinggi-di-dunia-1479389615

Kencana, Maulandy Rizky Bayu. (2018). Menteri PUPR Kebut Aturan Pengawasan kualitas Rumah Subsidi. https://www.liputan6.com/bisnis/read/3258246/menteri-pupr-kebutaturan-pengawasan-kualitas-rumah-subsidi

Kotler, Philip. (2000) Marketing Management, Millenium edition. New Jersey: Prentice Hall Intl, Inc.

McCarthy, E. Jerome. (1964). Basic Marketing: A Managerial Approach. Hardwood III: R. D. Irwin.

Mowen, John C. (1993). Consumer Behavior. New York: Macmillan Publishing Company.

Sugiyono. (2015). Metode Penelitian Pendidikan (Pendekatan Kuantitatif, Kualitatis, dan R\&D). Bandung: Alfabeta. 